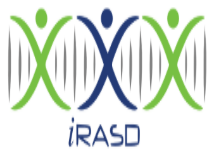

iRASD Journal of Management

Volume 4, Number 1, 2022, Pages 01 - 16

Journal Homepage:

https://journals.internationalrasd.org/index.php/jom
RASD

JOURNAL OF MANAGEMENT

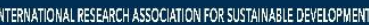

\title{
Formal Institutional Distance and cross-border M\&A-Contract Ineffectiveness: Moderating Role of Advisory Organizations
}

\author{
Nadia Hanif ${ }^{1}$, Abida Hafeez ${ }^{2}$, Noman Arshed ${ }^{3}$ \\ ${ }^{1}$ Assistant Professor, UE Business School, Division of Management and Administrative Science, University of \\ Education, Lahore, Pakistan. Email: nadiahanif77@yahoo.com \\ ${ }^{2}$ Assistant Professor, Department of Economics, Division of Management and Administrative Science, University of \\ Education, Lahore, Pakistan. Email: abida.hafeez@ue.edu.pk \\ ${ }^{3}$ Assistant Professor, Department of Economics, Division of Management and Administrative Science, University of \\ Education, Lahore, Pakistan. Email: noumanarshad@hotmail.com
}

\begin{tabular}{|c|c|c|}
\hline \multicolumn{3}{|l|}{ ARTICLE INFO } \\
\hline \multicolumn{3}{|l|}{ Article History: } \\
\hline Received: & December & 07,2021 \\
\hline Revised: & January & 19,2022 \\
\hline Accepted: & January & 19,2022 \\
\hline Available Online: & January & 25,2022 \\
\hline \\
\hline \multirow{2}{*}{\multicolumn{3}{|c|}{ Advisory Governance }} \\
\hline & & \\
\hline \multicolumn{3}{|c|}{ Develoned Fconomies } \\
\hline \multirow{2}{*}{\multicolumn{3}{|c|}{ Emerging Economies }} \\
\hline Formal Institutions & & \\
\hline \multicolumn{3}{|l|}{ Mergers } \\
\hline Acquisitions & & \\
\hline
\end{tabular}

OPEN

ACCESS

\section{ABSTRACT}

\begin{abstract}
Advisory organizations on cross-border mergers and acquisition deals performed as advisory governance can fill the distance between the formal institutional environment of host and home economies. This study examined the formal institutional distance between emerging and developed economies and their role in M\&A initial contract ineffectiveness by expanding the phenomena of the pre-completion stage of M\&A-contracts. We examine our key questions using data of 832 cross-border M\&A-contracts of developed economies' firms with emerging economies' firms in the international business high-technology industry from 1984-2011. We find that formal institution distance explains part of the variation in the ineffectiveness of M\&A-contracts. Further the gain from the external capabilities provided by advisory organizations helps in reducing the effect of institutional distance on the M\&A-contract ineffectiveness.
\end{abstract}

(C) 2022 The Authors, Published by iRASD. This is an Open Access article under the Creative Common Attribution Non-Commercial 4.0

\section{Introduction}

Past few decades witnessed organizations have expanded ahead of their home country in pursuit of rivals to grow in new global markets (Ghoshal, 1987; Hitt, Hoskisson, \& Kim, 1997). International investment in mergers and acquisitions (M\&A) has accomplished unprecedented altitudes in recent years. Dewing (1921) stated that crossborder expansion strategy through M\&A can turn into anything from terrific success to miserable failures. Similar conclusions are given by (Ansoff, 1971; Kierulff, 1981; Kitching, 1967; Livermore, 1935; Meeks, 1977; Nelson, 1959). Porter (1989) and Young (1981) stated that the rate of cross-border acquisitions failure is elevated as compared to its success stories. Historically firms still abandon up to 25 percent of their acquisition at some point during the pre-completion stage (Holl \& Kyriaziz, 1996). A corporate acquisition "is the buying by one company (the bidder or acquiring firm) of a large part of the assets or securities of other firm (the target firm), normally for restructuring the operations of the acquired/target entity". Building and managing the buyer and seller relationship cross borders M\&A transactions are challenging (Dikova, Sahib, \& Van Witteloostuijn, 2010; Meyer \& Altenborg, 2008). Hence the role of contract in governing business transaction between buyers and sellers has been considerably discussed in supply chain management literature. Contracts enable the buyer and seller to coordinate through clearly identifying roles, responsibilities and rights of each party. In addition, contracts define the procedures $\&$ rules of the deal, it shields against opportunism (Poppo \& Zenger, 2002) and provide the remedies for contingencies (Argyres \& Mayer, 2007; Lumineau \& Malhotra, 2011; Salbu, 1997). Contracts confirms the effective monitoring of the deal that can control potential 
partner's opportunistic behavior and cut agency costs (Balachandran \& Williams, 2018), which in turn assist the contracting parties to attain equitable and efficient deal outcomes (Poppo \& Zenger, 2002). Supplier and buyer relationship through contract is well documented in supply chain management while considering institutional theory and relationship-governance construct which emerged owing to perceived limits embedded in contract (Poppo \& Zenger, 2002; Poppo \& Zhou, 2014; Shou, Zheng, \& Zhu, 2016). In many cross-border M\&A transaction deal's partners (acquiring and target firms) fail to realize the intended goals, and sometimes even fail to complete the M\&A transaction (henceforth, M\&A-contracts) (Berry, Guillén, \& Zhou, 2010; Dikova et al., 2010). This happened due to the relational cooperation problems arise due to misalignment of actions (Dyer \& Hatch, 2006; MacDuffie \& Helper, 2007; Yan \& Dooley, 2013) and incompatible strategies (Meyer \& Altenborg, 2008), the strength of which is determined by institutional environment (Brockman, Rui, \& Zou, 2013). Contracts have inherent adaptability-limits of the institutional environment which allow the contract parties to behave opportunistically in realms unspecified in the contracts (Shou et al., 2016). The influence of institutions on deal coordination is largely prevailing in emerging economies, where national institutions are not well-established (Dikova et al., 2010), sub-national institutions constantly evolving and reveal large divergence (Meyer \& Gelbuda, 2006; Shi, Sun, \& Peng, 2012). Which give rise the construct of perceived ineffectiveness of M\&A-contract at the phase when two merging parties are entering into the exchange transaction. To control any potential contingencies, which can be a hazard in the success of contract completion that is the outcome of adaptability-limits of contract vis-à-vis the broader institutional environment, the transaction/deal parties move toward any suitable governance mechanisms (Poppo \& Zenger, 2002; Shou et al., 2016) such as the role of advisory organization are used as advisory governance in this study.

Advisory governance referred to the appointment of advisory service organizations on the M\&A-contract to govern the transaction by the acquirer firm who are specialized in advisory and consultancy business. These organization's strategic resource is intellectual capital (Barney, 1991) who are experienced and professional people and offer excellent and expert opinions to their clients. The highly experienced and professional people, their relational networking, broad access to capital markets, knowledge management and flows capabilities so on, worldwide, provide advisory organizations excellence in consultancy services. The acquirer firm lacks the capability to evaluate the distance of host country institutions from home country institutions specifically when the host country is emerging, and institutions create turbulence due to institutional uncertainty. For cross-border M\&Acontracts the acquiring firm cannot depend only on its own experience and relations and outsource governance services of advisory organization on transaction for expert, accurate, inclusive and timely information, and opinions. While taking advantage from the resourcebased view (Arya \& Lin, 2007; Lavie, 2006; Popli, Ladkani, \& Gaur, 2017) the acquirer firm drive capabilities and resources from the advisory organizations to decrease the influence of institutional environment distance on the M\&A-contract performance on initial phase of M\&A-contract.

This study contributed to international business literature through various ways. First, the study analyzed pre-merger intermediary phase understood as initial cross-border M\&A deal completion processing period. Second, in literature, only a few studies Kim and Song (2017) have been investigated the institutionally tempted M\&A-contract ineffectiveness by selecting different governance-mechanism such as prior experience in international M\&A deals. The cross-border M\&A has inherent adaptability-limits of contracts ascend from distance in national institutions of merging parties lead to perceived contract ineffectiveness measured by M\&A deal abandonment between the acquiring and target firms during deal initiation to completion phase. Therefore, this study investigated the impact of home and host countries institutional distance on the likelihood of cross-border M\&A deal failure mentioned as M\&As contract ineffectiveness. Third, this study examined the contextual role of advisory governance measured as advisory organization's consultancy on the cross-border M\&A deal's intermediary phase while interacting with institutional distance. Fourth, study accessed SDC platinum to identify firms from developed economies including North America (US, Canada, France) and Japan (Dikova et al., 2010) entering in M\&A-contracts with emerging economies firms including Brazil, Russia, India, China and South Africa (BRICS) that were announced in the international business high-technology industries with SIC codes 31, 11-14, 21-24 and 40-42 between 1984 to 2011 . Overall, the 
study combined macro-level adaptability-limits in cross-border contracts defined as institutional distance with micro-level organizational advisory governance mechanism associated with cross-border M\&As motivated by perceived ineffectiveness of contracts during the intermediary phase of M\&A-contract. Finally, the conceptual framework of this study is based on institutional theory to provide insights on how institutional distance increases the likelihood of M\&A contract ineffectiveness. For this study, we took formal institutions at the national level and the interaction role of advisory governance encouraged by resource-based view on controlling the unexpected and contingent influence of institutions to decrease the likelihood of contract ineffectiveness.

\subsection{Phases of M\&A-Contract}

Dikova et al. (2010) studied "How are firms sold?', Boone and Mulherin (2007) depicted that the acquisition procedure is consisting three events and two periods.

The private acquisition phase commences when "a selling company appoints a banker and evaluates the number of prospective buyers to contact"(Boone \& Mulherin, 2007 , p. 849). The selected bidders usually sign standstill/confidentiality contracts by which the bidder obtain confidential information, give consent on not to create a spontaneous bid, and show preliminary consideration. Usually, a seller can negotiate with manifold bidders, while only one bidder announces a public bid for the selling firm. Although the first phase consists of the initial bargaining's, or negotiations, between seller (here the target firm in M\&A deals) and several bidding/buyer firms (the acquirer firm in the acquisition deal). When the official announcement in the financial press has been done, in this phase, only two final parties - the target and the bidder -enter into the phase of a public takeover and sign initial contract. It commences with the press declaration date and closes with the resolution of contract (completion or abandoned) date. The second phase, or "intermediary" stage, may take of numerous months to be get completed. "when the two firms sign an initial merger contract, the investors and market keep on receiving most upto-date information about the firm values and deal as the negotiation course unfolds" (Hotchkiss, Qian, \& Song, 2005, p. 1). Existing literature, specifically, published in the legal or financial research, has revealed that the new information that becomes public, within this particular intermediary phase, radically influence the returns and risks of acquisition arbitrage (Hsieh \& Walkling, 2005; Mitchell \& Pulvino, 2001; Mitchell, Pulvino, \& Stafford, $2002,2004)$. Given the unavoidable renegotiation/rebargaining of the initial contract as latest information becomes accessible to bidding and selling parties, the facility to renegotiating the initial agreement to an acceptable end for the concerned parties, determine the probability of initial acquisition contract completion or it may leave both the parties dissatisfied (Davidson, Rosenstein, \& Sundaram, 2002). Hence, once the suitable target is acknowledged and intermediary phase started, the preparation of the public offer normally entails the services of outside legal, financial and accounting advisers (Dikova et al., 2010) specifically if the firms are from diverse institutional environment. Therefore, from the literature it can be concluded that the first phase (private takeover period) of M\&A-contract starts from private initiation and ends at public announcement when selected acquirer firms sign initial contract with target (Zhou, Xie, \& Wang, 2016). The second phase can be called as public takeover period in which processing of initial contract is being done to make it effective. The first and second phase is pre-completion stage of M\&A deal which ends with the resolution/completion of the transaction. After the completion of M\&A deal the formal integration process starts between the firms which basically called as postcompletion stage of M\&A-contracts. Hence graphically the three stages and two phases of M\&A-contracts can be explained as below

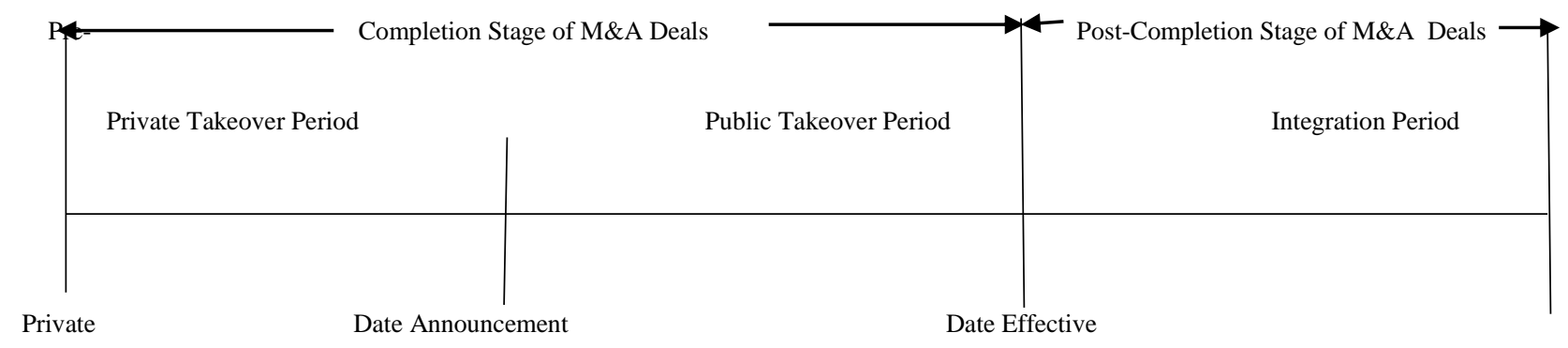




\section{Theories and Hypothesis Development \\ 2.1. Formal Institutional Distance and M\&A-Contracts}

At the second stage of M\&A transaction the two parties target and acquirer firms sign (Dikova et al., 2010; Kim \& Song, 2017; Zhou et al., 2016) or enter an initial contract. M\&A-contracts encountered with unavoidable conflicts (Dikova et al., 2010), which arises "when one party perceives another as interfering with its goal attainment" (Samaha, Palmatier, \& Dant, 2011, p. 100). A substantial literature has extensively investigated the role of governance mechanism through relationships and formal contracts in extenuating conflict and opportunism (Heide, 1994; Jap \& Anderson, 2003). The first mechanism is related to social structure embedded in economic activities (Granovetter, 1985) and later focusing on economic incentives, and legal contractual arrangements (Heide \& John, 1992; Williamson, 1985). Contracts ensure parties to realize promises and obligations to perform activities in the future (Macneil, 1977). According to Williamson (1991), contracts ensure mutually approved procedures and policies for assigning any necessary adaptation in a transaction since contracts can offer to customize dealings. Well specified formal contracts encourage resolution in exchange transactions by enforcing penalty charges for the severity of exchange parties. A specified-formal contract offers trusted, highly cooperative and longterm exchange relationship between the parties and reduced the probability and severity of any potential risk due to which an exchange can unprotected. contracts confirm effective monitoring of the deal partner that can control potential partner's opportunistic behavior and cut agency costs (Balachandran \& Williams, 2018), which in turn assist the contracting parties to attain equitable and efficient deal outcomes (Poppo \& Zenger, 2002).

Past literature has treated governance through the contract as a unidirectional construct and studied its effects in an international context such as contract completeness (Dikova et al., 2010; Kim \& Song, 2017), specificity (Mooi \& Ghosh, 2010) and complexity (Poppo \& Zhou, 2014; Reuer \& Arino, 2007). Some scholars examined role of contracts at firm level. They concluded that formal contracts are too limited to mitigate the governance of inter-organizational repeated exchange relationships. As such, repeated exchanges based on relationships and trust (Heide \& John, 1992; Macneil, 1977; Noordewier, John, \& Nevin, 1990) which reduces the cost of transaction. Antia and Frazier (2001) studied contracts from ex-ant and ex-post perspectives, they argued that the design of contracts is much different from its actual enforcement cost. According to these authors, enforcement of contracts is significant in buyer and supplier relationships (Antia \& Frazier, 2001). The enforcement cost is primarily determined by institutional environment (North, 1990), which is a little researched topic in contract's enforcement within cross-border M\&A exchanges.

Although contract performs governance through constraining any potential conflict and shielding against opportunistic behavior to either party. In many transactions, deal partners fail to realize the intended goals and sometimes even did not resolve the contract (Berry et al., 2010; Dikova et al., 2010). This happened because the contract has unavoidable inherent adaptability-limits to economic, social, legal and cultural uncertainty (Shou et al., 2016), which are causes of contract ex-post enforcement cost (Antia \& Frazier, 2001), even when it is specified enough to highlight the expectations of each party to mitigate the risk of any potential misunderstanding (Malhotra \& Lumineau, 2011). The institutional environment is prescribing several interests, laws, regulations, rules, belief systems, cultural schemes and as well time conceptions (Dille \& Söderlund, 2011; Levitt \& Scott, 2017). At the public announcement phase, the two merging firms entered into an initial formal contract (Dikova et al., 2010; Kim \& Song, 2017). After the public announcement, the two firms need to interact with inter-institutional in addition to interorganizational factors at the national level for successful completion of the contract. For example, the firms in M\&A exchange needed to deal with various formal and informal institutions. These bodies include regulatory bodies for court-contest deals, capital markets for the attainment of updated information, banks for cash flows and other transactions, norms and attitudes. While interacting with people, insurance firms, agencies to ensure corporate social responsibility or protection of labors and employees etc. Here it is worthy of presenting the case of United States as discussed by Dikova et al. (2010) while interpreting North (1990) view that "the institutions necessary to accomplish economic exchange vary in their complexity"- it includes hierarchy of rules (statute law, constitutional law, bylaws and common law), internal and external capital markets (Kim \& Song, 2017) and cultural complexities (Dikova et al., 2010), in association determine the range of formal 
structure of privileges in a well-formulated exchange and fix how expensive it is to make an exchange. For example, the US principal federation law governs corporate mergers and acquisitions and prohibits those merger contracts which may have the potential for monopoly or may lessen the competition in the market substantially. The international M\&A-contracts required to face more institutional complexity as they must have approved from regulatory scrutiny needed to interact with high cultural sensitivity (Dikova et al., 2010). Dikova et al. (2010) stated that well established formal institutions, for example judicial and political regulations, third party enforcement and economic rules (such as contracts) decline the uncertainty among individual and organization transactions. The adverse regulatory agencies and the ruling of courts are one of the reasons for contract terminations (Hoskisson, Eden, Lau \& Wright, 2000) and as well impact negatively the innovation performance of economies at national level (Arshed, Hanif, Aziz \& Croteau, 2022). According to Kim and Song (2017), intermediary (initial contract processing) phase needs to deal with internal and external capital markets for any upcoming accurate financial information (Kim \& Song, 2017). Khanna and Palepu (2010) stated that institutions voids are general problem in emerging markets which limits the access of every latest and accurate information during this initial contract processing phase. Kim \& Song (2017) further stated that institutional voids in an external capital market such as stock market not only restrict flow of financial resources but also create information asymmetry in economy. After initial agreement of M\&A transaction the acquirer firm confronted with release of new information which drive the renegotiation of the initial M\&A-contract and may leave the parties dissatisfied (Dikova et al., 2010; Kim \& Song, 2017). In this case the unavailability of transparent information become the main culprit for contract ineffectiveness. In addition, the cash versus stock payment are less complex and leads to less likelihood of contract ineffectiveness (Dikova et al., 2010). But if the financial structure of a country is not sufficiently strong it would lead to difficulty in cash and other resource flows and may delays the payment that could be another potential reason of contract ineffectiveness.

Hence the institution complexity of the M\&A contract is high when the two parties are from highly diverse institutional environment such as a M\&A contract between firms from developed and emerging economies. As stated by Kostova and Zaheer (1999) that acquirer can easily adjust and understand the host country legal environment if it is more identical to its home environment. Since the lack of transparent information and financial institutional structure, complexity of transaction due to institutional complexity and the pressure for acquiescence with regulations, laws and rules that "a foreign acquirer cannot easily comprehend can obstruct the contract completion and cause the contract ineffectiveness or it may require a substantial amount of time to reach at a resolution of initial M\&A-contract of the transaction" (Dikova et al., 2010, p. 227). Further, Hanif, Jianfeng and Babar, 2020 found that the home and host country's institutional distance while interacting with acquired ownership negatively influence the post-acquisition success of the acquiring firm. Hence $\mathrm{H} 1$ of the study is as follows

Hypothesis 1: The distance between home and host country's formal institutions increases the likelihood of M\&A-contract ineffectiveness.

\subsection{Moderating Role of Advisory Governance on Institutions and M\&A- Contract Ineffectiveness}

Resource based view (RBV) suggest that the advisory organizations hired by acquirer on M\&A-contracts assist in reducing the probability of contract ineffectiveness through their professional advisory capabilities. A very famous global advisory organization Morgan Stanley stated that they "advise, originate, trade, manage and distribute capital for government, institutions and individuals and always do so with the standard of excellence" (Stanley, 2018). What advisory organization can offer on M\&A contracts? The advisory organization is supplemented with experienced, professionals and financial advisors who conduct timely, in-depth analysis of companies, industries, markets and world economies which provide trading, sales and market-creation services to generate superior and sustainable returns for their clients through exploring new systems of investment opportunities. One of the services provided by advisory organizations is to connect capital situated in diverse markets with new ideas so that creative products can be produced, business can grow, and communities can flourish. Advisory organizations through their 
broad access and opportunities initiatives around the world can help in broadening the access of capital for multicultural innovators. Organizations, corporations and governments around the world rely on advisory organizations and their professional opinions in investment banking and capital markets for raising the capital world-wide (Stanley, 2018). The service firms whose business is consultancy/advisory the strategic asset for those organizations is intellectual capital (Barney, 1991). Intellectual capital can be defined as the stocks and flows of intangible capabilities and resources (Martín-de Castro, 2014) of advisory service organizations. Further intellectual capital can be identifying within an organization through different assets including culture, capabilities, processes, intellectual property, strategies (Hsu \& Fang, 2009) and most importantly personnel (human capital), its capability of knowledge management (Hamel, 1998) and the value embedded in its relationships (relational networks). This view fully identifies the intellectual capital as a strategic asset, the core of which is relational network processes. Therefore, it can be argued that the experienced professionals and advisors constitute intellectual capital for advisory organizations as a strategic asset and localize it in the generation, management, configuration and exchange of knowledge. When the acquirer firm entering into M\&Acontracts with across home country target firm, the acquirer firm lacks the information about host economies' due to distance in institutional environment, specifically if the host country is emerging. For that reason, the acquirer firm outsources the services of advisory organizations under the resourced based view to govern the whole M\&A-contract by driving their unique, specialized, expert knowledge and global networking capabilities and resources. While approving the RBV, advisory governance directs the acquirer towards better deal outcomes in the long run (Servaes \& Zenner, 1996) and facilitate in realizing the competitive advantage in evaluating the transaction at individual and national level.

According to RBV, the advisory governance provides specialized governance on M\&A transaction through expert opinions to the acquirers which reduce the formal institutional distances between two markets which in turn reduce the transaction cost and increase the likelihood of effective completion of the M\&A-contract through their unique, expert, and specialized intellectual capabilities. We took ineffectiveness of contract in the form of those $M \& A$-contracts which fail to reach at completion and further study the acquirer appointment of advisory governance on the deal due to perceived ineffectiveness of contracts. We proposed following hypothesis from RBV about the role of advisors as advisory governance as a moderator on contract ineffectiveness caused by distances in institutional environment and how advisory governance can reduce the likelihood of M\&A-contract ineffectiveness:

Hypothesis 2: As advisory organizations are appointed as advisory-governance on M\&A deal, the relationship between formal institutional distance and contract-ineffectiveness decreases.

\section{Methodology 3.1. Data}

The data in this study is a sample of international M\&A in high-technology industry from 1984 to 2011. We used SDC Platinum organized by Thomson Reuters worldwide to access data on all those firms commenced acquisition transaction across their home country. This is important to state that while selecting the sample we follow the approach taken by Dikova et al. (2010) that our sample is restricted to only those mergers and acquisitions transactions which have reached at the public announcement. In addition, we did not include those mergers which were announced privately or were abandoned before the public announcement or reached completion but announced and completed thoroughly in private. In this study, we took only those M\&A transactions occurred in Hi-technology industry including Biotechnology, Computer Equipment, Electronics and Communications. We took developed economies' firms from North America (US, Canada, France) and Japan entering merger-contracts with emerging economies' firms from Brazil, Russia, India, China and South Africa (BRICS) that were announced in an international business high-technology industry with SIC codes 31, 11-14, 21-24 and 40-42 between 1984 to 2011. The data include variables regarding initial contract announcement, contract ineffectiveness, contract withdrawn and contract completion of the transaction and some other information regarding financials, transaction value and status of firms. For formal institutional variables the dataset comprised of target and acquirer nations from PRS group international country risk guide (ICRG) statistics (Dikova et al., 2010) and World Development Indicators (Berry et 
al., 2010; Kim \& Song, 2017). After excluding missing observations, the dataset is reduced from 934 to 847 .

We choose high-technology industry for many reasons. Firstly, although every industry is being influenced by national institutional environment at same pace, but hightechnology industry is suitable for analyzing the role of formal institutions because strong legal, financial and educational institutions reduce the barriers to innovations as technological developments are encouraged by strong institutional environment (Ahn \& York, 2011; Galang, 2012; Schneider, Schulze-Bentrop, \& Paunescu, 2010; Zhu, Wittmann, $\&$ Peng, 2012). Secondly, the acquisition has substantial value in the technology industry.

For this study, we choose BRICS as host country whereas firms from North America and Japan as global acquisition partners. We choose BRICS as host country because emerging markets often suffering from institutional uncertainty (Luo, 2007), consist of high appropriation risk (Oxley, 1999), and institutional voids (Doh, Rodrigues, Saka-Helmhout, \& Makhija, 2017). In addition, a significant percentage of announced acquisition deals involve emerging economies have failed before completion. In their Zhou et al. (2016) study 3483 acquisition deals involving BRICS countries which were almost $32.5 \%$ of the announced deals failed to reach at resolution. For example, in our sample of total $934 \mathrm{M} \& \mathrm{~A}$ deals in HITechnology industry involving BRICS, $29.87 \%$ of announced initial contracts became ineffective. The failure rate of acquisition deals in emerging economies is much higher than $18 \%$ failure rate of acquisition among developed economies (Dikova et al., 2010). Business confidence survey showed that more than $70 \%$ of European firms lack trust in contract effectiveness in China, and all suggest the advancement in institutions as a key driver for Chinese economy (European chamber in China and Ronald Berger 2013).

Our study attempted to control the sample bias occurred in the study of Dikova et al. (2010) as they took only developed economies in their analysis of the institutional influence on pre-acquisition contract. Developed countries institutional environment have common traits such as all of them endorse the improvement of market economy rules of exchange. These countries shielded by regulations, rules and laws that are country specific which is quite different from growing rules of exchange (contracts) in emerging economies. Therefore, the developed and emerging economies institutional environment distance is substantial irrespective of geographic proximity. Dikova et al. (2010) argued that firms facing high institutional distance are less likely to attempt an acquisition transaction on the basis of that they only considered acquisitions among developed economies, but their findings were conservative, as stated by Dikova et al. (2010, p. 231) that "they are likely to underestimate the influence of institutional factors". In present study, we included M\&A attempts from developed economies in BRICS economies within Hi-technology industry and this way, by and large, the findings of our analysis are fully estimating the institutional factors.

\subsection{Measures}

A contract entails an agreement among two or more entities, featuring clauses exhibiting the consideration, which means to exchange with something valuable and beneficial. Contracts is of different types, i.e., oral and written. The written contract is worthy due to its feature of providing proof and vice versa. Abiding of contact is mandatory; otherwise, it results in a breach of contract. Breach of contract can have occurred without any legal excuse, that is if at least one entity does not fulfill any condition of the contract. Breach of a contract also comes across when either of the entity involved, does not abide by the regulations of the contract (Hill \& Hill, 2018). We took breach of M\&A initial agreement as contract ineffectiveness. Contract ineffectiveness is measured similarly used by Brug and Sahib (2018), is a dummy variable and given the value 1 for M\&A which were failed to complete after initial signed or oral contract at the phase of public announcement, and 0 if M\&A-contracts were completed and enter in maturity stage for further agreements and integration processes. According to the median number of days in completion of M\&Acontract is approximately 62 (Muehlfeld, Rao Sahib, \& Van Witteloostuijn, 2012) and 68 average number of days (Zhou et al., 2016) for all the deals. In our sample of developed to emerging economies the mean number of days for all the M\&A-contract completion is 110 days. Hence, we also considered the cross-border M\&A-contracts that were pending until 
December 2014, which is three years after 2011, to be withdrawn and implied their contract ineffectiveness status as 1 . The ineffectiveness of contract is different from taken by Shou et al., (2016) in their study since they took perceived ineffectiveness of contract, but in our study, we took actual ineffective contracts which were announced but not reached at resolution and hence failed to reach at completion stage. For our dependent variables we examined dates of announcement, completion and about the status of acquisitions given by SDC Platinum.

The four independent variables in our study are about formal institutions. The first two independent variable taken from PRS group international country risk guide statistics. This dataset is providing information for each country and for each year. We took distance for each year between each two country's institutions involve in contract while using Euclidean distance formula. We took data from 1984 to 2011 for all the selected countries in sample. We put value of institutional distance to each firm for each relevant year of contract ineffectiveness and duration of deal for relevant country. ICRG provide data regarding a country risk level of regulatory indicators. We took those regulatory factors from ICRG which potentially influence the international acquisition deals. For highlighting these regulatory measures, we consulted lawyers who highlighted us indicators relating to following text:

1) Overall Law and Order Condition

2) Overall democratic accountability

3) Role of external and internal conflicts on procedures and legislation

4) Role of corruption on procedures and legislation

5) Role of military influence in politics

For other two financial regulatory institutional variables we took measures from past studies (Berry et al., 2010; Kim \& Song, 2017) and included financial measures on following indicators

1) Current account balance (\% of GDP)

2) Market capitalization of listed domestic companies (\% of GDP)

3) Real effective exchange rate index $(2010=100)$

4) Domestic credit to private sector (\% of GDP)

5) Listed domestic companies, total

\section{Table 1}

Factor Analysis of Independent Variables

\begin{tabular}{|c|c|c|c|c|}
\hline Variables & Factor1 & Factor2 & Factor3 & Factor4 \\
\hline \multicolumn{5}{|l|}{ Internal Conflict } \\
\hline External Conflict & 0.4723 & & & \\
\hline Corruption & 0.8316 & & & \\
\hline Military in Politics & & 0.4143 & & \\
\hline Law and Order & & 0.6046 & & \\
\hline Democratic Accountability & & -0.5062 & & \\
\hline Current Account Balance ( $\%$ of GDP). & & & 0.7896 & \\
\hline $\begin{array}{l}\text { Market Capitalization of Listed Domestic } \\
\text { Companies (\% of GDP) }\end{array}$ & & & & 0.6021 \\
\hline $\begin{array}{l}\text { Real Effective Exchange Rate Index } \\
(2010=100)\end{array}$ & & & & 0.4457 \\
\hline $\begin{array}{l}\text { Domestic Credit to Private Sector (\% of } \\
\text { GDP) }\end{array}$ & & & 0.5658 & \\
\hline Listed Domestic Companies, Total & & & & 0.5611 \\
\hline Factors (Variables) & Procedural & Legal & Financial & Information \\
\hline & Complexity & Enforceability & $\begin{array}{l}\text { Resources } \\
\text { Flow }\end{array}$ & Transparency \\
\hline
\end{tabular}

To highlight factors upon these terms we conducted unrestricted Principal Component (PCA) factor analysis. PCA produce two factors from regulatory measures titled as legal enforceability and procedural complexity which explain $79 \%$ of total variance. For financial indicators we obtain two variables titled as information transparency and resource flow which explain $60 \%$ of total variance. 
As stated by Dikova et al. (2010) that firms hire advisory organizations (advisory governance) on the second phase of M\&A-contract. For advisory governance we took $1=$ for acquirers who appointed advisors and 0 otherwise.

\subsection{Control Variables}

We took control variables at firm level. Experience indicates whether the acquirer firm has experience of completed M\&A contracts. $1=$ those acquirers who have past merger experience, otherwise 0 . This variable is important as concluded by Dikova et al. (2010) that experience in M\&A contracts decrease the likelihood of contract ineffectiveness. Percentage sought is the percentage of ownership expected by acquirer in a M\&A contract. The higher the percentage the more will be stake an acquirer is looking in a contract, the more it creates difficulty to approve the contract. Status of target and acquirer indicates whether the target firm is public, private, government owned firm, joint venture or subsidiary. If the firm status is public, government owned, joint venture and subsidiary the more complex and difficult the contract to be approved as the firm is relating to some other governance structure which increases the liability of the acquirer towards these additional governances. Resource similarity refers to the percentage of resources similar between target and acquirer firms calculated by formula used by Chen, Meng, and Li (2018) in their study. Less resource relatedness increases the chances of M\&A contract ineffectiveness. M\&A type refers to whether the merger contract was disclosed dollar value, undisclosed dollar value and stake purchase. We operationalized this construct as categorical variable. In addition, we used year and industry as control variables.

\section{Research Findings}

We estimated binary logistic regression taking contract ineffectiveness as the dependent variable. Since we took 1984- 2011-time period for BRICS countries firms M\&Acontracts with developed countries' firms. Only few firms in our data have experience in M\&A-contracts in same industry. For example, ICN Pharmaceuticals Inc entered merger contract in 1995 with Tuobin Chemicals (China) and then second time in 1996 with Leksredstva and Polypham in Russian Federation. This way ICN Pharmaceuticals Inc entered M\&A-contract three times during whole period 1984-2011. We found same trend in our sample that only the $8.5 \%$ firms appeared on different years not more than an average of 5 years which restricted us in applying panel data techniques for current study. This way the dataset is highly unbalanced panel and forced us to use pooled regression analysis while considering country as dummy variable.

We applied hierarchical regression model for observing the impact of advisory governance as moderator while considering the country dummy variable for contract ineffectiveness. We only considered mergers which reached at initial contract and showed the status of transaction whether its effective or withdrawn/no status/ineffective.

Table 2 shows the summary statistics and correlations, which do not reveal multicollinearity problem. All the values of correlation are well below the accepted threshold level, that is 0.7 . The examination of variance inflation factor (VIF) presented that all the values are well below the standard cut off value of 10 . For the analysis of the current study, we applied hierarchical logit regression. Since some authors center-the-mean of variables while applying interaction effect on their model but as stated by Brambor, Clark, and Golder (2006) that centering of variables can produce misleading and meaningless results (Echambadi \& Hess, 2007). Although centering-the-mean ease the interpretation of regression coefficients in hierarchical regression but the chances of misleading results from center-the-mean directs us to represent some graphical representation of interaction effects to discuss the marginal effect. 
Table 2

Descriptive Statistics of M\&A Transaction Analysis

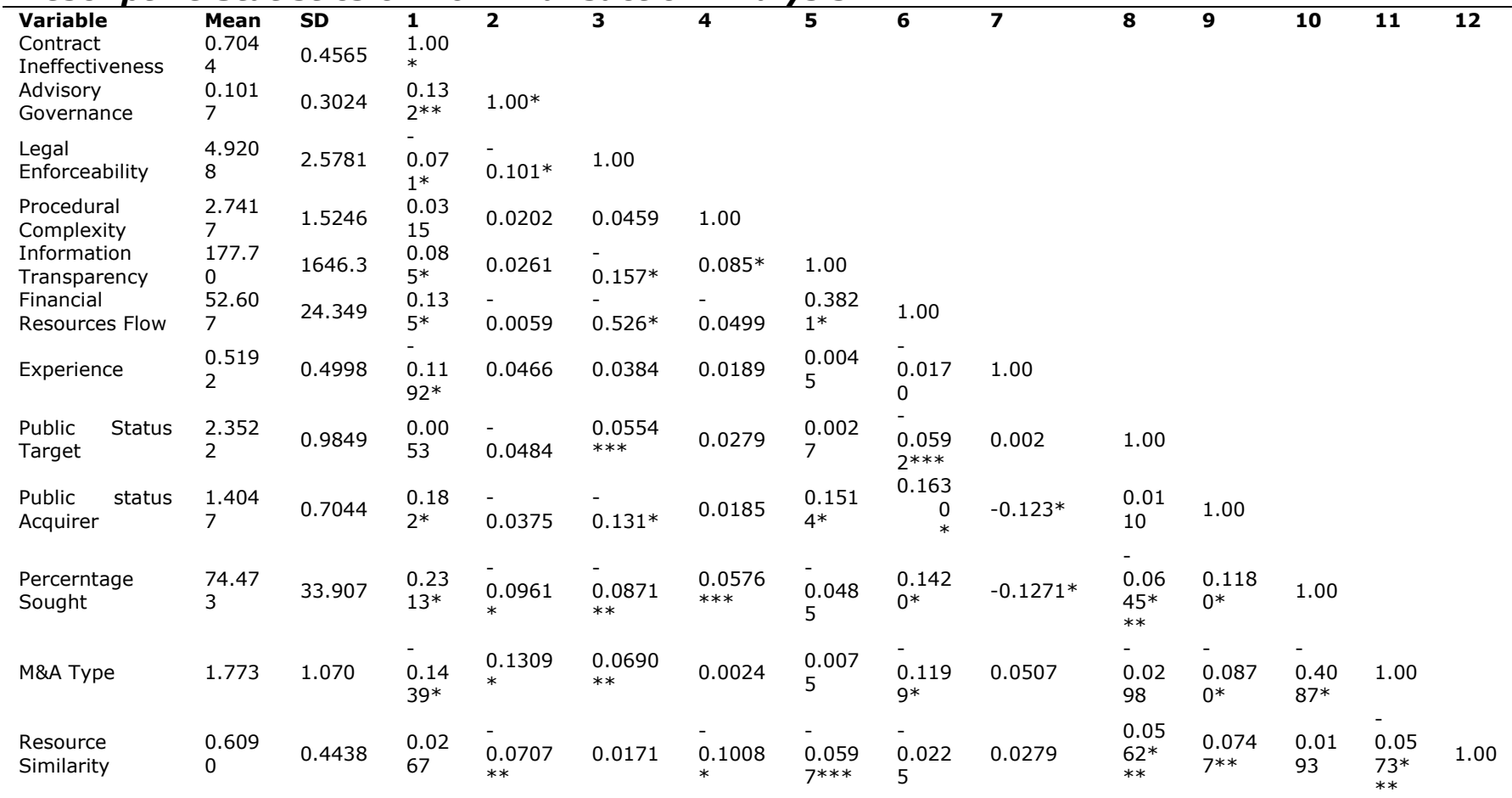

At $* 0.01$, at $* * 0.05$, at $* * * 0.10$

\subsection{Moderation role of advisory governance on contract ineffectiveness and institutions}

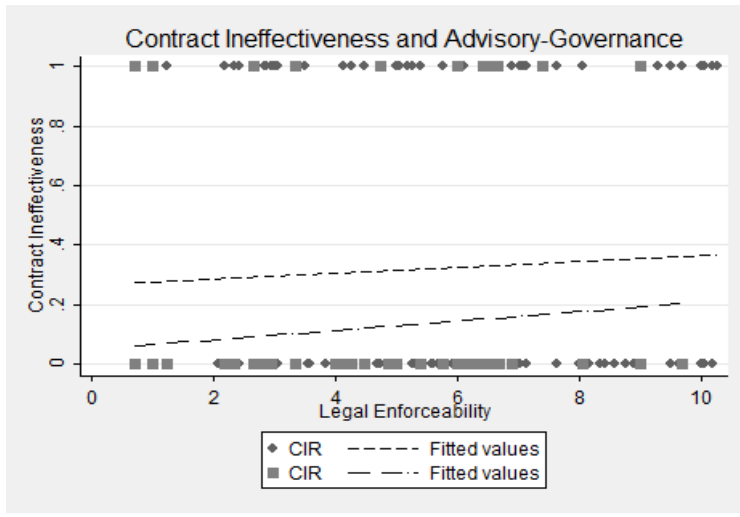

Figure 1

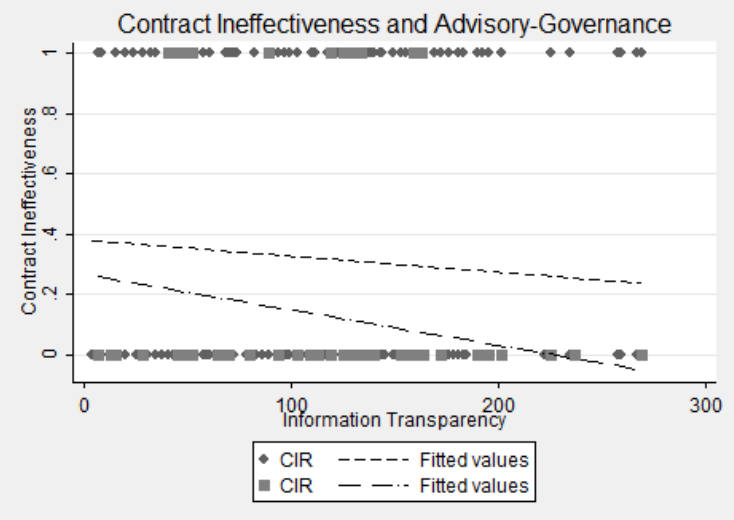

Figure 3

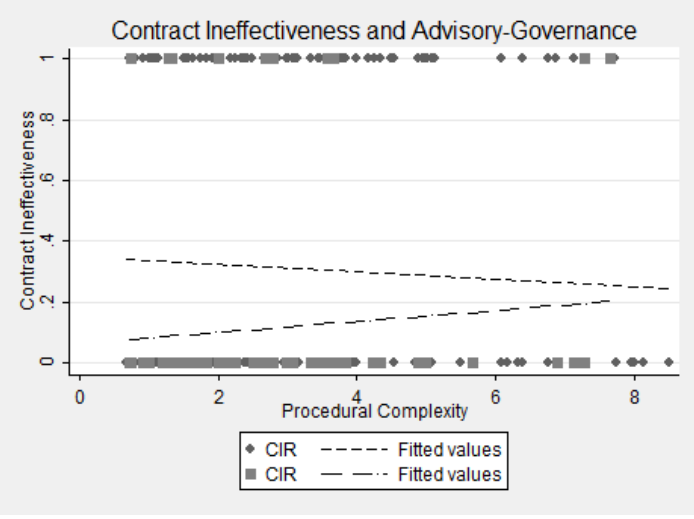

Figure 1

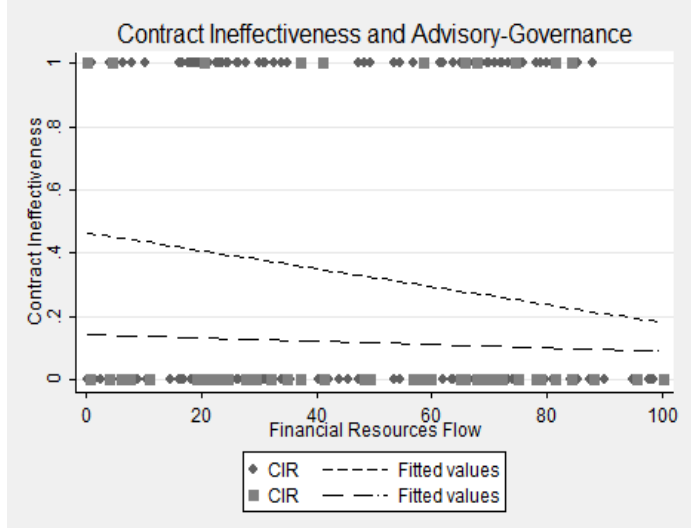

Figure 4

Figure 1, 2, 3 and 4 shows the lines are not parallel. In interaction graphs 1, 2, 3 and 4 it highlighted that the relationship between dependent variable contract ineffectiveness and independent variables procedural complexity, information transparency and financial resources flow highly influenced by the advisory governance of the advisors. Whereas the relationship between legal enforceability and contract ineffectiveness is slightly 
moderated by advisory governance. In contract effectiveness regression analysis, we followed Ruckman (2005) and reported only coefficients, standard errors, the Wald chi square hypothesis for null hypothesis, the value of log likelihood at convergence, number of observations (Dikova et al., 2010). Table 3 shows the results of the hypotheses 1 and hypotheses 2 of hierarchical regression. In Model 1 all the control variables are highlighted including percentage sought, status of target and acquirer are significant at 0.05 and 0.01 level of significance, respectively. Model 2 additionally shows all the independent variables; here legal enforceability is significantly influencing contract ineffectiveness at 0.05 level of significance and control variable including percentage sought, status of target, status of acquirer is significant. Model 3 also included advisory governance which is significant at 0.01 level of significance.

Table 3

M\&A Contract Ineffectiveness Results

\begin{tabular}{|c|c|c|c|c|}
\hline & $\begin{array}{l}\text { M\&A Contr } \\
\text { Model1 } \\
\text { Controls } \\
\text { Only }\end{array}$ & $\begin{array}{l}\text { Ineffectiven } \\
\text { Model } 2 \\
\text { Institutions }\end{array}$ & $\begin{array}{l}\text { ess } \\
\text { Model3 } \\
\text { Institutions } \\
\text { and Advisory } \\
\text { governance }\end{array}$ & $\begin{array}{l}\text { Model4 } \\
\text { Institutions and } \\
\text { Advisory governance } \\
\text { Interaction Effect }\end{array}$ \\
\hline Intercept & $\begin{array}{l}-55.417 \\
(0.482)\end{array}$ & $\begin{array}{l}-84.827 \\
(68.426)\end{array}$ & $\begin{array}{l}-76.011 \\
(69.572)\end{array}$ & $\begin{array}{l}-87.158 \\
(70.796)\end{array}$ \\
\hline Experience & $\begin{array}{c}0.215 \\
(0.171)\end{array}$ & $\begin{array}{l}0.209 \\
(0.173)\end{array}$ & $\begin{array}{c}0.251 \\
(0.176)\end{array}$ & $\begin{array}{c}0.261 \\
(0.177)\end{array}$ \\
\hline Status Target & $\begin{array}{c}-0.217 * * \\
(0.107)\end{array}$ & $\begin{array}{l}-0.221 \\
(0.108)\end{array}$ & $\begin{array}{c}-0.248 * * \\
(0.112)\end{array}$ & $\begin{array}{c}-0.233 * * \\
(0.113)\end{array}$ \\
\hline Status Acquirer & $\begin{array}{l}-0.604^{*} \\
(0.157)\end{array}$ & $\begin{array}{l}-0.6016 \\
(0.158)\end{array}$ & $\begin{array}{c}-0.638 * \\
(0.163)\end{array}$ & $\begin{array}{l}-0.641^{*} \\
(0.162)\end{array}$ \\
\hline Percentage Sought & $\begin{array}{c}-0.012 * \\
(0.003)\end{array}$ & $\begin{array}{l}-0.012 \\
(0.003)\end{array}$ & $\begin{array}{c}-0.012 * \\
(0.003)\end{array}$ & $\begin{array}{c}-0.011 * \\
(0.003)\end{array}$ \\
\hline M\&A Type & $\begin{array}{c}0.021 \\
(0.080)\end{array}$ & $\begin{array}{c}0.031 \\
(0.079)\end{array}$ & $\begin{array}{c}0.105 \\
(0.071)\end{array}$ & $\begin{array}{c}0.168 * * \\
(0.084)\end{array}$ \\
\hline Resource Similarity & $\begin{array}{l}-0.018 \\
(0.198)\end{array}$ & $\begin{array}{l}-0.020 \\
(0.200)\end{array}$ & $\begin{array}{c}-0.110 \\
(0.204)\end{array}$ & $\begin{array}{c}-0.139 \\
(0.207)\end{array}$ \\
\hline Year & $\begin{array}{c}0.028 \\
(0.021)\end{array}$ & $\begin{array}{l}0.0421 \\
(0.034)\end{array}$ & $\begin{array}{c}0.038 \\
(0.034)\end{array}$ & $\begin{array}{c}0.043 \\
(0.035)\end{array}$ \\
\hline Industry & & $\begin{array}{l}-0.047 \\
(0.075)\end{array}$ & $\begin{array}{l}-0.089 \\
(0.076)\end{array}$ & $\begin{array}{l}-0.096 \\
(0.077)\end{array}$ \\
\hline Legal Enforcement & & $\begin{array}{l}0.179 * * \\
(0.084)\end{array}$ & $\begin{array}{c}0.147 * * * \\
(0.086)\end{array}$ & $\begin{array}{l}0.10 * * * \\
(0.076)\end{array}$ \\
\hline Procedural Complexity & & $\begin{array}{l}0.082 \\
(0.081)\end{array}$ & $\begin{array}{l}0.096 \\
(0.082)\end{array}$ & $\begin{array}{c}0.059 \\
(0.082)\end{array}$ \\
\hline Information Transparency & & $\begin{array}{l}-0.004 \\
(0.002)\end{array}$ & $\begin{array}{l}-0.004 \\
(0.002)\end{array}$ & $\begin{array}{l}-0.005 \\
(0.002)\end{array}$ \\
\hline Financial Resources Flow & & $\begin{array}{c}0.009 \\
(0.008)\end{array}$ & $\begin{array}{c}0.010 \\
(0.009)\end{array}$ & $\begin{array}{l}0.009 \\
(0.009)\end{array}$ \\
\hline Advisory Governance & & & $\begin{array}{l}-1.930 \\
(0.423)\end{array}$ & $\begin{array}{l}-6.410 * \\
(2.178)\end{array}$ \\
\hline $\begin{array}{l}\text { Legal Enforceability*Advisory } \\
\text { Governance }\end{array}$ & & & & $\begin{array}{l}0.214 \\
(0.189)\end{array}$ \\
\hline $\begin{array}{l}\text { Procedural Complexity* } \\
\text { Advisory Governance }\end{array}$ & & & & $\begin{array}{l}0.820^{*} \\
(0.292)\end{array}$ \\
\hline $\begin{array}{l}\text { Information Transparency* } \\
\text { Advisory Governance }\end{array}$ & & & & $\begin{array}{l}-0.015 \\
(0.010)\end{array}$ \\
\hline $\begin{array}{ll}\text { Financial Resources } & \text { Flow* } \\
\text { Advisory Governance } & \end{array}$ & & & & $\begin{array}{l}0.053^{*} \\
(0.021)\end{array}$ \\
\hline Cases in analysis & 832 & 832 & 832 & 832 \\
\hline Log Likelihood & -432.253 & -428.988 & -414.290 & -406.920 \\
\hline Wald chi-square & $116.52 *$ & $123.06 *$ & $152.45 *$ & $167.91 *$ \\
\hline
\end{tabular}

Model 4 shows all the variables including interaction term. This shows that the advisory governance is significantly related with contract ineffectiveness at 0.01 level of significance. Whereas the interaction term financial resources flow and procedural complexity are significant at 0.01 level of significance. Hypothesis 1 is accepted only for legal enforceability influence on likelihood of contract ineffectiveness. Hypothesis 2 is 
accepted for procedural complexity and financial resources flow which means that advisory governance reduces the impact of formal institution distance including procedural complexity and financial resources flow on contract ineffectiveness.

The graphs in figures 5 and 6 are post regression interaction plots for procedural complexity and financial resources flow. The graph is showing that advisory governance increases the likelihood of contract completion between acquirer and target firms through minimizing the part of variation in formal institutional distances.

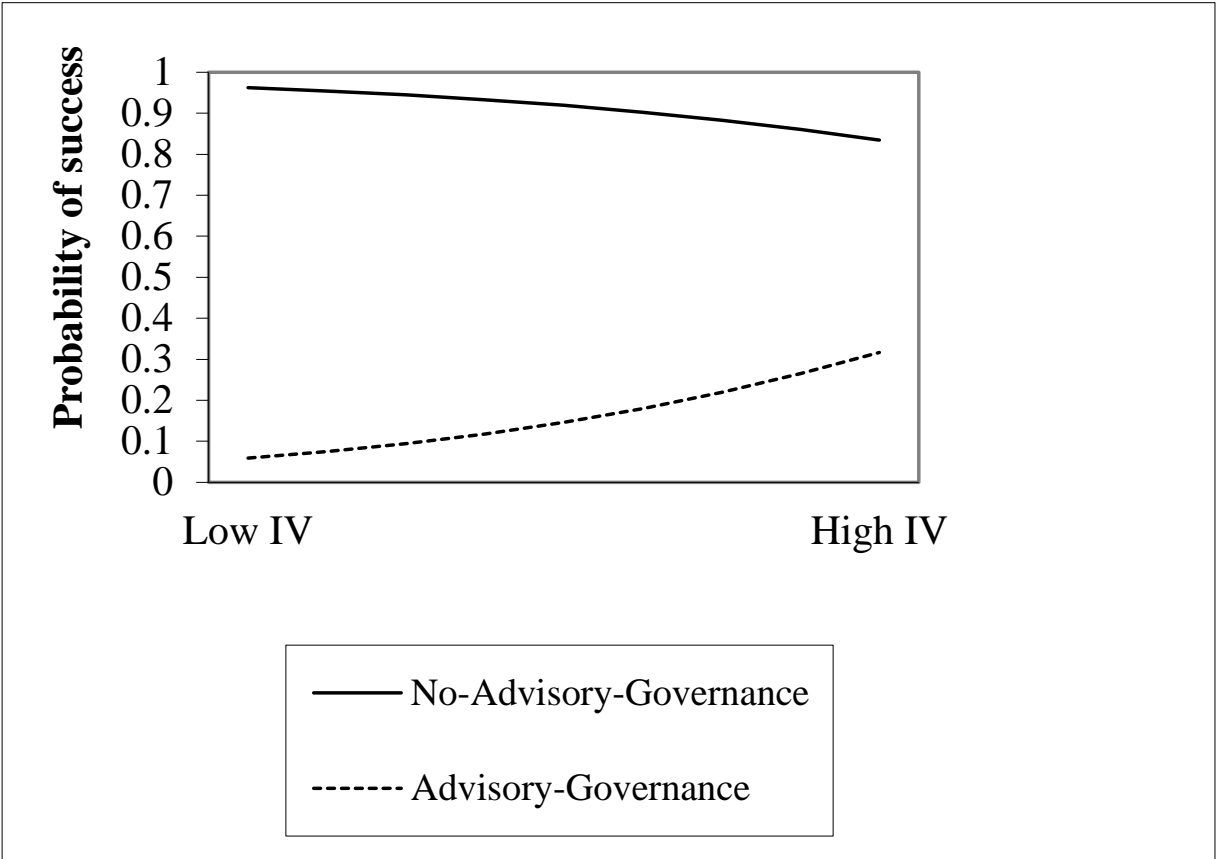

Figure 5: Post-regression moderating role of advisory governance on procedural complexity contract ineffectiveness

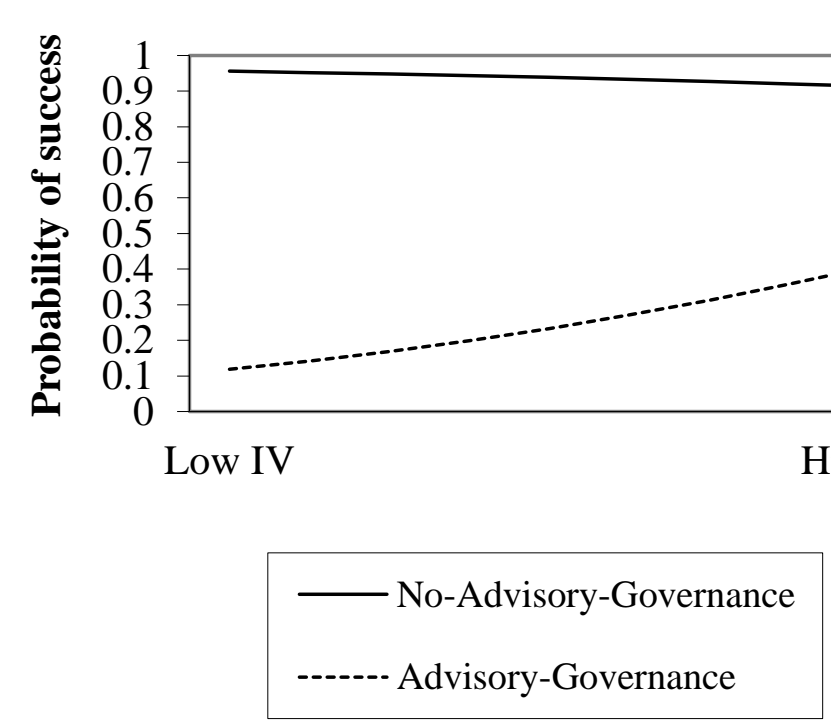

Figure 6: Post-regression moderating role of advisory governance on financial resource flows contract ineffectiveness

\section{Discussion and Conclusion}

In present study, we studied a phenomenon of role of advisory governance appointed by acquirer on M\&A-contracts on pre-completion stage to circumvent from the potential cost of transaction occurred in cross-border M\&A due to contracts ineffectiveness and duration. The model in present study identified the national formal institutions that impact contract ineffectiveness. The main implication of this study is that we took advantage of RBV on institutional distance of M\&A-contracting parties in configuration of the 
advisory governance mechanism appointed by acquirer on pre-completion stage of M\&Acontracts. Despite the prevalent trend of cross-border M\&A transactions several initial contracts become ineffective. To find the reasons of contract ineffectiveness, in present study we tried to highlight few formal institutional factors in addition to studied by (Dikova et al., 2010; Kim \& Song, 2017). In addition, we studied how the acquirer can reduce the substantial tangible and intangible transaction cost in the form of ineffective M\&A-contracts by appointing advisory governance mechanism on M\&A-contracts initial processing phase which was neglected topic in past research.

Although employing advisory governance on pre-completion stage of M\&A contracts increase the cost of transaction for acquirer firm but how advisory governance can save firm from facing substantial cost in the form of contract infectiveness is the subject of matter in present study. We applied institution theory to combine the macro level institutional distances and firm level cost of exchange in the form of ineffective M\&Acontracts. While taking advantage from the resource-based view acquirer drive capabilities and resources from the advisory governance to decrease the influence of institutional distance on the M\&A-contract performance (ineffectiveness) on initial processing phase of M\&A-contract.

For data we considered developed economies' firms including North America (US, Canada, France) and Japan entering merger and acquisition-contracts with emerging economies' firms including Brazil, Russia, India, China and South Africa (BRICS) that were announced in international business high-technology industry with SIC codes 31, 11-14, 2124 and 40-42 between 1984 to 2011. Results indicate that the advisory governance weakens the negative impact of formal institution distance including procedural complexity and flow of financial resources on contract ineffectiveness and increase the likelihood of contract to be effective.

\section{Study Limitations and Future Recommendations}

As any small piece of research cannot contemplate every limitation, the present study restricted to the sample of only high-technology industry. We applied pooled regression analysis while taking country dummy owing to very few numbers of firms repeated for only few years because the sample was limited to only one industry. We could highlight only few formal institutional factors some other factors such as economic distance, geographic distance influence on M\&A-contract ineffectiveness can be highlighted. In addition to national institutional distance the role of firm level characteristics of seller and buyer can be highlighted as percentage sought in present study put new insights on M\&A research in hi-technology industry. Other than advisory organization as governance mechanism such as political ties can also be highlighted to decrease the influence of institutions on likelihood of M\&A-contract ineffectiveness. Present study shed light on few formal institutional factors which effect the pre-completion stage of M\&A contract processing. In addition to formal institutions future researchers can identify whether advisory governance moderate the role of informal institutions such as normative and cognitive rules etc. The moderating influence of advisory governance on institutions influence on M\&A-contract ineffectiveness identified that appointing advisory governance could enable acquirers to overcome formal institutional distance and increase the likelihood of contracts effectiveness by reducing the potential substantial cost of transaction failure. This study shed new insights on the importance of advisory organizations on M\&A precompletion stage. In addition to evaluating the M\&A transactions at firm level, advisory organizations also assist the acquirer to control and decrease the influence of the national formal institutions.

\section{References}

Ahn, M. J., \& York, A. S. (2011). Resource-based and institution-based approaches to biotechnology industry development in Malaysia. Asia Pacific Journal of Management, 28(2), 257-275.

Ansoff, H. I. (1971). Acquisition Behavior of US manufacturing firms, 1946-1965: 19461965: Nashville: Vanderbilt University Press. 
Arshed, N., Hanif, N., Aziz, O., \& Croteau, M. (2022). Exploring the potential of institutional quality in determining technological innovation. Technology in Society, 68, 101859.

Antia, K. D., \& Frazier, G. L. (2001). The severity of contract enforcement in interfirm channel relationships. Journal of Marketing, 65(4), 67-81.

Argyres, N., \& Mayer, K. J. (2007). Contract design as a firm capability: An integration of learning and transaction cost perspectives. Academy of Management Review, 32(4), 1060-1077.

Arya, B., \& Lin, Z. (2007). Understanding collaboration outcomes from an extended resource-based view perspective: The roles of organizational characteristics, partner attributes, and network structures. Journal of Management 33(5), 697-723.

Balachandran, B., \& Williams, B. (2018). Effective governance, financial markets, financial institutions \& crises. Pacific-Basin Finance Journal, 50(9), 1-15.

Barney, J. (1991). Firm resources and sustained competitive advanatge. Journal of Management, 17(1), 99-120.

Berry, H., Guillén, M. F., \& Zhou, N. (2010). An institutional approach to cross-national distance. Journal of International Business Studies, 41(9), 1460-1480.

Boone, A. L., \& Mulherin, J. H. (2007). How are firms sold? The Journal of Finance, 62(2), 847-875.

Brambor, T., Clark, W. R., \& Golder, M. (2006). Understanding interaction models: Improving empirical analyses. Political analysis, 14(1), 63-82.

Brug, t., Hans, \& Sahib, R., Padma. (2018). Abandoned deals: the merger and acquisition process in the electricity and gas industry. Energy Policy, 123, 230-239.

Chen , F., Meng, Q., \& Li, X. (2018). Cross-border post-merger integration and technology innovation: A resource-based view. Economic Medelling, 68, 229-238.

Cimilluca, D. (2007). Buyout firms fuel a record; pace of M\&A pacts could start to slow amid tighter credit. Wall Street Journal.

Davidson, N., Wallace, Rosenstein, S., \& Sundaram, S. (2002). An Empirical analysis of cancelled mergers, board composition and ownership structure. Applied Financial Economics, 12(7), 485-491.

Dewing, A. S. (1921). A statistical test of the success of consolidations. The Quarterly Journal of Economics, 36(1), 84-101.

Dikova, D., Sahib, P. R., \& Van Witteloostuijn, A. (2010). Cross-border acquisition abandonment and completion: The effect of institutional differences and organizational learning in the international business service industry, 1981-2001. Journal of International Business Studies, 41(2), 223-245.

Dille, T., \& Söderlund, J. (2011). Managing inter-institutional projects: The significance of isochronism, timing norms and temporal misfits. International Journal of Project Management, 29(4), 480-490.

Doh, J., Rodrigues, S., Saka-Helmhout, A., \& Makhija, M. (2017). International business responses to institutional voids: Springer.

Dyer, J. H., \& Hatch, N. W. (2006). Relation-specific capabilities and barriers to knowledge transfers: creating advantage through network relationships. Strategic management journal, 27(8), 701-719.

Echambadi, R., \& Hess, J. D. (2007). Mean-centering does not alleviate collinearity problems in moderated multiple regression models. Marketing Science, 26(3), 438445.

Galang, R., Martin, N. (2012). Government efficiency and international technology adoption: The spread of electronic ticketing among airlines. Journal of International Business Studies, 43(7), 631-654.

Ghoshal, S. (1987). Global strategy: An organizing framework. Strategic management journal, 8(5), 425-440.

Granovetter, M. (1985). Economic action and social structure: The problem of embeddedness. American journal of sociology, 91(3), 481-510.

Hagedoorn, J. (2002). Inter-firm R\&D partnerships: an overview of major trends and patterns since 1960. Research policy, 31(4), 477-492.

Hamel, G. (1998). Strategic Flexibility: Managing in a Turbulent Economy: Wiley, Chichester, UK.

Hanif, N., Wu, J., \& Babar, A. B. (2021). Linking ownership acquired in Chinese firms to post-acquisition innovation performance: role of institutional distance. Chinese Management Studies.

Heide, J. B. (1994). Interorganizational governance in marketing channels. The Journal of Marketing, 71-85. 
Heide, J. B., \& John, G. (1992). Do norms matter in marketing relationships? The Journal of Marketing, 32-44.

Hill, N., Gerald , \& Hill, T., Kathleen (2018). Legal Dictionary Retrieved 25th, February, 2018, from https://legal-dictionary.thefreedictionary.com/breach+of+contract

Hitt, M. A., Hoskisson, R. E., \& Kim, H. (1997). International diversification: Effects on innovation and firm performance in product-diversified firms. Academy of Management journal, 40(4), 767-798.

Holl, P., \& Kyriaziz, D. (1996). The determinants of outcome in UK take-over bids. International Journal of the Economics of Business, 3(2), 165-184.

Hoskisson, R. E., Eden, L., Lau, C. M., \& Wright, M. (2000). Strategy in emerging economies. Academy of Management journal, 43(3), 249-267.

Hotchkiss, E. S., Qian, J., \& Song, W. (2005). Holdups, renegotiation, and deal protection in mergers.

Hsu, Y.-H., \& Fang, W. (2009). Intellectual capital and new product development performance: The mediating role of organizational learning capability. Technological Forecasting and Social Change, 76(5), 664-677.

Jap, S. D., \& Anderson, E. (2003). Safeguarding interorganizational performance and continuity under ex post opportunism. Management science, 49(12), 1684-1701.

Khanna, T., \& Palepu, K. (2010). Exploiting institutional voids as business opportunities. Harvard Business Review, 1-20.

Kierulff, H. E. (1981). Finding the best acquisition candidates. Harvard Business Review, 59(1), 66-\&.

Kim, H., \& Song, J. (2017). Filling institutional voids in emerging economies: The impact of capital market development and business groups on M\&A deal abandonment. Journal of International Business Studies, 48(3), 308-323.

King, D. R., Slotegraaf, R. J., \& Kesner, I. (2008). Performance implications of firm resource interactions in the acquisition of R\&D-intensive firms. Organization science, 19(2), 327-340.

Kitching, J. (1967). Why do mergers miscarry. Harvard Business Review, 45(6), 84-101.

Kostova, T., \& Zaheer, S. (1999). Organizational legitimacy under conditions of complexity: The case of the multinational enterprise. Academy of Management Review, 24(1), 64-81.

Lavie, D. (2006). The competitive advantage of interconnected firms: An extension of the resource-based view. Academy of Management Review, 31(3), 638-658.

Levitt, R. E., \& Scott, W. R. (2017). Institutional Challenges and Solutions for Global Megaprojects The Oxford Handbook of Megaproject Management (pp. 96-117): Oxford University Press Oxford.

Livermore, S. (1935). The success of industrial mergers. The Quarterly Journal of Economics, 50(1), 68-96.

Lumineau, F., \& Malhotra, D. (2011). Shadow of the contract: How contract structure shapes interfirm dispute resolution. Strategic management journal, 32(5), 532-555.

Luo, Y. (2007). Are joint venture partners more opportunistic in a more volatile environment? Strategic management journal, 28(1), 39-60.

MacDuffie, J. P., \& Helper, S. (2007). Collaboration in supply chains: With and without trust.

Macneil, I. R. (1977). Contracts: Adjustment of long-term economic relations under classical, neoclassical, and relational contract law. Nw. UL Rev., 72, 854.

Malhotra, D., \& Lumineau, F. (2011). Trust and collaboration in the aftermath of conflict: The effects of contract structure. Academy of Management journal, 54(5), 981-998.

Martín-de Castro, G. (2014). Intellectual capital and the firm: some remaining questions and prospects. Knowledge Management Research \& Practice, 12(3), 239-245.

Meeks, G. (1977). Disappointing marriage: A study of the gains from merger (Vol. 51): CUP Archive.

Meyer, C., \& Altenborg, E. (2008). Incompatible strategies in international mergers: The failed merger between Telia and Telenor. Journal of International Business Studies, 39(3), 508-525.

Meyer, K. E., \& Gelbuda, M. (2006). Process perspectives in international business research in CEE. Management International Review, 46(2), 143-164.

Mooi, E. A., \& Ghosh, M. (2010). Contract specificity and its performance implications. Journal of Marketing, 74(2), 105-120. 
Muehlfeld, K., Rao Sahib, P., \& Van Witteloostuijn, A. (2012). A contextual theory of organizational learning from failures and successes: A study of acquisition completion in the global newspaper industry, 1981-2008. Strategic management journal, 33(8), 938-964.

Nelson, R. L., \& research, N. b. o. e. (1959). Merger movements in American industry, 1895-1956: Princeton University Press Princeton.

Noordewier, T. G., John, G., \& Nevin, J. R. (1990). Performance outcomes of purchasing arrangements in industrial buyer-vendor relationships. The Journal of Marketing, 8093.

North, C., Douglass. (1990). Institutions, institutional change and economic performance: Cambridge: Cambridge university press.

Oxley, J. E. (1999). Institutional environment and the mechanisms of governance: the impact of intellectual property protection on the structure of inter-firm alliances. Journal of Economic Behavior \& Organization, 38(3), 283-309.

Popli, M., Ladkani, R., M, \& Gaur, A., S. (2017). Business group affiliation and postacquisition performance: An extended resource-based view. Journal of Business Research, 81, 21-30.

Poppo, L., \& Zenger, T. (2002). Do formal contracts and relational governance function as substitutes or complements? Strategic management journal, 23(8), 707-725.

Poppo, L., \& Zhou, K. Z. (2014). Managing contracts for fairness in buyer-supplier exchanges. Strategic management journal, 35(10), 1508-1527.

Porter, M. E. (1989). From competitive advantage to corporate strategy Readings in strategic management (pp. 234-255): Springer.

Reuer, J. J., \& Arino, A. (2007). Strategic alliance contracts: Dimensions and determinants of contractual complexity. Strategic management journal, 28(3), 313-330.

Ruckman, K. (2005). Technology sourcing through acquisitions: evidence from the US drug industry. Journal of International Business Studies, 36(1), 89-103.

Salbu, S. R. (1997). Evolving contract as a device for flexible coordination and control. American Business Law Journal, 34(3), 329-384.

Samaha, S. A., Palmatier, R. W., \& Dant, R. P. (2011). Poisoning relationships: Perceived unfairness in channels of distribution. Journal of Marketing, 75(3), 99-117.

Schneider, M. R., Schulze-Bentrop, C., \& Paunescu, M. (2010). Mapping the institutional capital of high-tech firms: A fuzzy-set analysis of capitalist variety and export performance. Journal of International Business Studies, 41(2), 246-266.

Servaes, H., \& Zenner, M. (1996). The role of investment banks in acquisitions. The Review of Financial Studies, 9(3), 787-815.

Shi, W., Sun, S. L., \& Peng, M. W. (2012). Sub-national institutional contingencies, network positions, and IJV partner selection. Journal of Management Studies, 49(7), 12211245.

Shou, Z., Zheng, X. V., \& Zhu, W. (2016). Contract ineffectiveness in emerging markets: An institutional theory perspective. Journal of Operations management, 46, 38-54.

Stanley, M. (2018). What we do Retrieved 2nd, November, 2018, from http://www.morganstanley.com/ideas/wellesley-munibond-women-in-science

Villalonga, B., \& McGahan, A. M. (2005). The choice among acquisitions, alliances, and divestitures. Strategic management journal, 26(13), 1183-1208.

Wang, L., \& Zajac, E. J. (2007). Alliance or acquisition? A dyadic perspective on interfirm resource combinations. Strategic management journal, 28(13), 1291-1317.

Weber, Y. (1996). Corporate cultural fit and performance in mergers and acquisitions. Human relations, 49(9), 1181-1202.

Williamson, O., E. (1985). The Economic Institutions of Capitalism. New York: Free Press.

Williamson, O., E. (1991). Comparative economic organization: The analysis of discrete structural alternatives. Administrative science quarterly, 269-296.

Yan, T., \& Dooley, K. J. (2013). Communication intensity, goal congruence, and uncertainty in buyer-supplier new product development. Journal of Operations management, $31(7-8), 523-542$.

Young, J. B. (1981). A conclusive investigation into the causative elements of failure in acquisitions and mergers. Handbook of mergers, acquisitions and Buyouts, 605-628.

Zhou, C., Xie, J., \& Wang, Q. (2016). Failure to complete cross-border M\&As:"to" vs. "from" emerging markets. Journal of International Business Studies, 47(9), 1077-1105.

Zhu, Y., Wittmann, X., \& Peng, W., Mike (2012). Institution-based barriers to innovation in SMEs in China. Asia Pacific Journal of Management, 29(4), 1131-1142. 